\title{
COMPARISON BETWEEN TWO TYPES OF ABDUCTION ORTHOTICS IN TREATING CONGENITAL CLUBFOOT
}

\section{COMPARAÇÃO ENTRE DUAS ÓRTESES DE ABDUÇÃO NO TRATAMENTO DO PÉ TORTO CONGÊNITO}

\author{
Luiz Carlos Ribeiro Lara ${ }^{1}$, Bruno Leite Gil ${ }^{2}$, Lucio Carlos de Azevedo Torres Filho ${ }^{2}$, Tarsila Pagnan Silva dos Santos ${ }^{2}$ \\ 1. Universidade de Taubaté (UNITAU), Department of Medicine, Hospital Universitário de Taubaté (HUT), Orthopedics and Traumatology Division, Foot and Ankle Group, Taubaté, SP, Brazil. \\ 2. Hospital Universitário de Taubaté (HUT), Orthopedics and Traumatology Division, Taubaté, SP, Brazil.
}

\begin{abstract}
Objective: The objective of this study was to analyze and compare the effectiveness of two types of abduction orthotics used for the feet, the Denis-Browne type (traditional) and the Dobbs type (dynamic), with regard to maintenance of deformity correction and prevention of recurrence. Method: In this comparative retrospective case study, information was collected from the medical records of children with idiopathic congenital clubfoot (CCF). We evaluated a total of 43 feet in 28 patients, which were divided into two groups. Group 1 was comprised of 16 patients with a total of 24 CCFs treated with the traditional orthotic device. Group 2 consisted of 12 patients with a total of 19 CCFs treated with the dynamic orthotic device. The statistical analysis used the ANOVA test to compare the categorical variables between the groups. A significance level of $5 \%$ was adopted ( $p$-value $\leq 0.05$ ). Results: In Group 1, recurrence was observed in 2 feet (8.33\%), and in 1 foot in Group 2 (5.26\%). No significant difference in effectiveness was seen between the two types of orthotic devices. Conclusion: Both abduction devices were seen to be effective in maintaining correction of congenital clubfoot deformities. There was no statistical significance between type of orthotic device and recurrence. Level of Evidence III, Retrospective Comparative Study.
\end{abstract}

Keywords: Congenital abnormalities. Foot deformities. Clubfoot. Foot orthoses.

\section{RESUMO}

Objetivo: Analisar e comparar a eficácia entre dois tipos de órtese de abdução para o pé, tipo Denis-Browne (tradicional) e a proposta por Dobbs (dinâmica), quanto à manutenção da correção das deformidades e da prevenção das recidivas. Método: Estudo de casos, retrospectivo e comparativo, com levantamento de prontuários de crianças com PTCI. Foram avaliados 28 pacientes, totalizando 43 pés, divididos em dois grupos: Grupo 1 - tratados com aparelho tradicional, 16 pacientes, 24 PTCl. Grupo 2 - tratados com aparelho dinâmico, 12 pacientes, totalizando 19 PTCl. A análise estatística comparou as variáveis categóricas entre os grupos com o teste ANOVA. Foi adotado nível de significância de $5 \%(p \leq 0,05)$. Resultados: No grupo 1, a recidiva ocorreu em dois pés (8,33\%) e no grupo 2 em um pé (5,26\%). Na comparação das duas órteses, a eficácia não apresentou diferença significante. Conclusão: Ambos os aparelhos de abdução mostraram-se eficazes na manutenção da correção das deformidades do pé torto congênito. Não ocorreu significância estatística em relação às órteses e a ocorrência de recidivas. Nível de Evidência III, Estudo Retrospectivo Comparativo.

Descritores: Anormalidades congênitas. Deformidades do pé. Pé torto. Órtoses do pé.

Citation: Lara LCR, Gil BL, Torres Filho LCA, Santos TPS. Comparison between two types of abduction orthotics in treating congenital clubfoot. Acta Ortop Bras. [online]. 2017;25(4):125-8. Available from URL: http://www.scielo.br/aob.

\section{INTRODUCTION}

Idiopathic congenital clubfoot (CCF) is the principal malformation of the musculoskeletal system, affecting one to two infants per 1000 live births. ${ }^{1-5}$ Affected children are born with feet with the following deformities: equinus, varus, adduct, cavus, and supinus. ${ }^{1-3,6-9}$

Today the conservative method described by Ponseti is used in almost all the services that treat this disease around the world. ${ }^{10}$ This method involves manipulations and the placement of a series of plaster casts on the feet and legs, which are changed weekly. At the same time that the casts are replaced, the need for tenotomy of the calcaneal tendon is assessed; this usually occurs around the sixth cast replacement, and is intended to definitively correct the equinus deformity. After the correction is achieved, the foot is kept in position using an abduction device with a fixed bar for 23 hours a day for three months and for 14 to 16 hours per day for another three or four years, usually corresponding to nighttime sleep in addition to daytime naps. ${ }^{11}$

This method is more effective when initiated in children under one year of age,,$^{6,10-14}$ but is also effective in patients aged between one and three years. ${ }^{14}$

All authors declare no potential conflict of interest related to this article. 
Proper use of the appliance is fundamental to maintaining the correction of the deformity. Failure to adhere to its use has a significant correlation with recurrence. . $^{3,4,9,12,15-18}$

The traditional orthesis is basically comprised of open-toe high-top boots which are connected with a bar. The angle of the boot and the length of the bar can be adjustable or fixed, depending on the variation. ${ }^{11}$ (Figure 1) Recently, Dobbs et al. ${ }^{9}$ developed a dynamic orthotic device which is individualized for leg movements, permitting greater comfort and tolerance for children and parents. (Figure 2) The objective of this study was to analyze and compare the effectiveness of these two types of abduction orthotics, traditional and dynamic, which are used to maintain the correction and prevent recurrence of idiopathic CCF.

\section{MATERIALS AND METHODS}

The medical records of patients with idiopathic CCF treated at the outpatient foot and ankle clinic at the Hospital Universitário

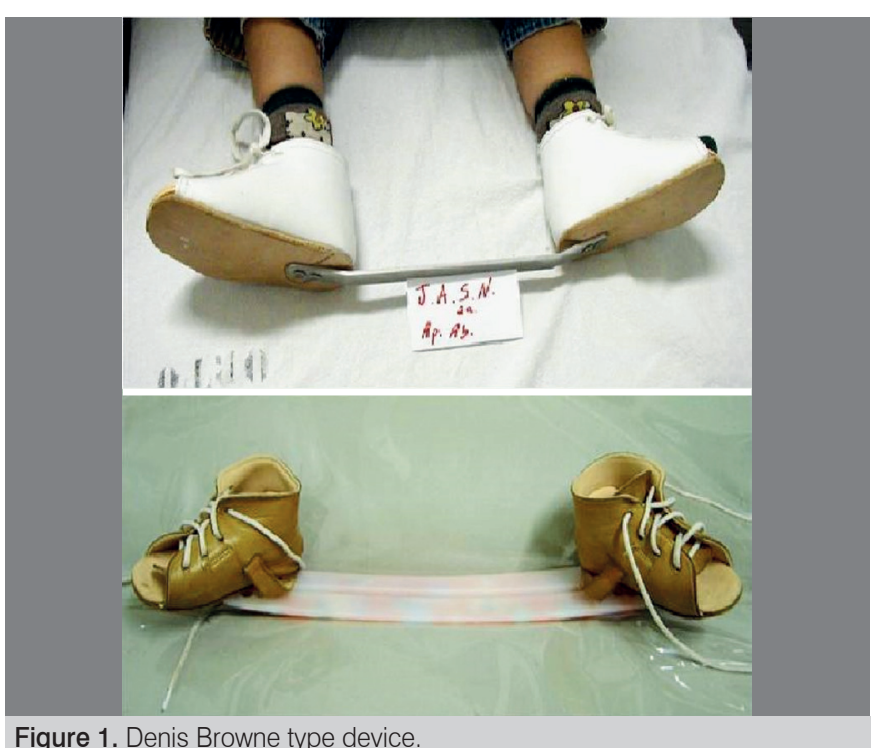

Figure 1. Denis Browne type device.

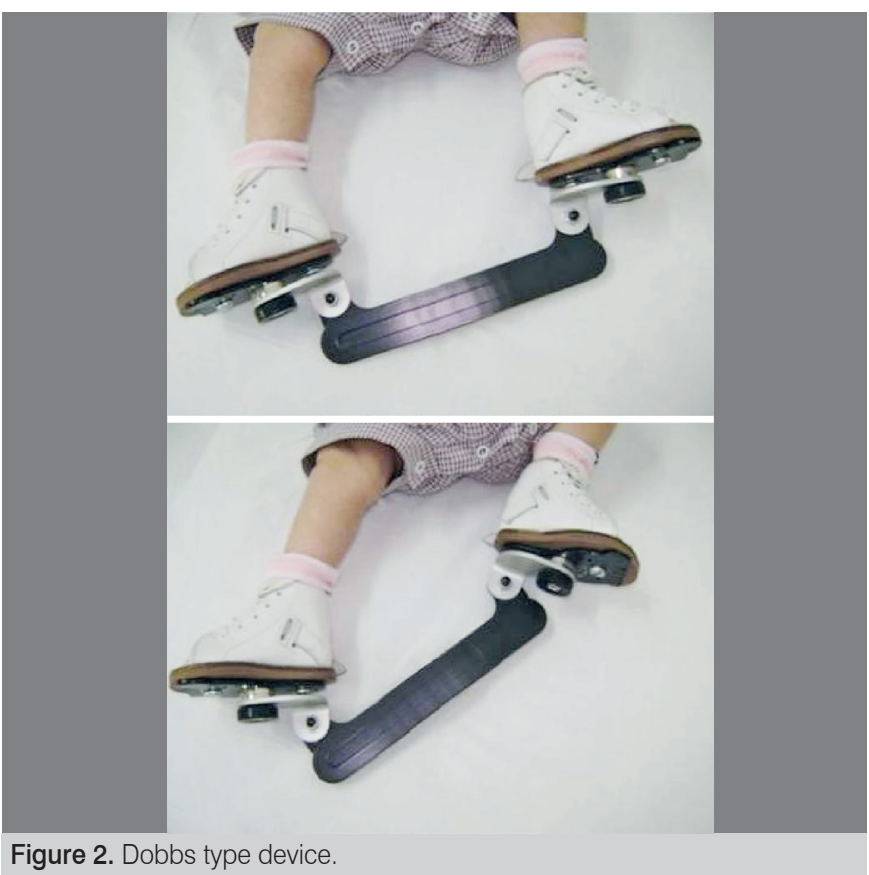

de Taubaté and in a private clinic of one of the authors were retrospectively analyzed.

All the cases of idiopathic CCF were classified according to the simplified Dimeglio method ${ }^{1,2}$ before the beginning of treatment. (Tables 1 and 2, Figure 3)

We evaluated 28 patients with idiopathic CCF (total of 43 feet) and divided them into two groups: Group 1 was treated with traditional abduction equipment as described by Denis-Browne. This type of abduction orthotic device maintains the correction of the CCF

Table 1. Traditional orthotic device (Group 1).

\begin{tabular}{|c|c|c|c|c|c|c|}
\hline Patients & Laterality & Side & Sex & \begin{tabular}{|l|} 
Dimeglio \\
\end{tabular} & Time of Use & Recurrence \\
\hline 1 & Unilateral & $\mathrm{L}$ & Male & IV & $3 y 5 m$ & -- \\
\hline 2 & Bilateral & $\mathrm{R}$ & Male & III & $5 y$ & -- \\
\hline 3 & Bilateral & L & Male & III & $5 y$ & -- \\
\hline 4 & Unilateral & $\mathrm{R}$ & Male & IV & $3 y$ & Yes \\
\hline 5 & Unilateral & $\mathrm{R}$ & Fem & III & $5 y$ & -- \\
\hline 6 & Bilateral & $\mathrm{R}$ & Male & III & $2 \mathrm{y} 6 \mathrm{~m}$ & -- \\
\hline 7 & Bilateral & $\mathrm{L}$ & Male & IV & $2 y 6 m$ & -- \\
\hline 8 & Unilateral & $\mathrm{L}$ & Male & III & $3 y$ & -- \\
\hline 9 & Bilateral & $\mathrm{R}$ & Male & III & $3 y$ & -- \\
\hline 10 & Bilateral & $L$ & Male & III & $3 y$ & -- \\
\hline 11 & Bilateral & $\mathrm{R}$ & Fem & III & $3 y$ & -- \\
\hline 12 & Bilateral & $\mathrm{L}$ & Fem & III & $3 y$ & -- \\
\hline 13 & Unilateral & $\mathrm{R}$ & Male & IV & $5 y$ & -- \\
\hline 14 & Unilateral & $\mathrm{R}$ & Male & II & $2 y 2 m$ & -- \\
\hline 15 & Bilateral & $\mathrm{R}$ & Male & 1 & $5 y$ & -- \\
\hline 16 & Bilateral & $\mathrm{L}$ & Male & III & $5 y$ & -- \\
\hline 17 & Bilateral & $\mathrm{R}$ & Male & 1 & $5 y$ & -- \\
\hline 18 & Bilateral & $\mathrm{L}$ & Male & IV & $5 y$ & -- \\
\hline 19 & Unilateral & $\mathrm{R}$ & Fem & III & $4 y$ & -- \\
\hline 20 & Bilateral & $\mathrm{R}$ & Male & III & $2 y$ & -- \\
\hline 21 & Bilateral & L & Male & III & $2 y$ & -- \\
\hline 22 & Bilateral & $\mathrm{R}$ & Fem & III & $2 y$ & Yes \\
\hline 23 & Bilateral & $L$ & Fem & III & $2 y$ & -- \\
\hline 24 & Unilateral & $\mathrm{R}$ & Male & IV & $4 y$ & -- \\
\hline
\end{tabular}

R: right; L: left; Fem: female; y: years; m: months; --: no recurrence.

Table 2. Dynamic orthotic device (Group 2).

\begin{tabular}{c|c|c|c|c|c|c}
\hline Patients & Laterality & Side & Sex & Dimeglio & Time of Use & Recurrence \\
\hline 1 & Bilateral & R & Male & III & $2 y$ & -- \\
\hline 2 & Bilateral & L & Male & I & $2 y$ & -- \\
\hline 3 & Bilateral & R & Male & III & $2 y$ & -- \\
\hline 4 & Bilateral & L & Male & IV & $2 y$ & -- \\
\hline 5 & Bilateral & R & Male & III & $3 y$ & -- \\
\hline 6 & Bilateral & L & Male & IV & $3 y$ & -- \\
\hline 7 & Bilateral & R & Male & III & $4 y$ & -- \\
\hline 8 & Bilateral & L & Male & II & $4 y$ & -- \\
\hline 9 & Unilateral & L & Male & III & $2 y 6 \mathrm{~m}$ & -- \\
\hline 10 & Unilateral & R & Male & I & $2 y$ & -- \\
\hline 11 & Bilateral & R & Male & IV & $2 y 2 \mathrm{~m}$ & -- \\
\hline 12 & Bilateral & L & Male & IV & $2 y 2 \mathrm{~m}$ & -- \\
\hline 13 & Unilateral & L & Fem & III & $3 y$ & -- \\
\hline 14 & Bilateral & R & Male & III & $2 y 6 \mathrm{~m}$ & Yes \\
\hline 15 & Bilateral & L & Male & III & $2 y 6 \mathrm{~m}$ & -- \\
\hline 16 & Unilateral & L & Male & III & $3 y$ & -- \\
\hline 17 & Unilateral & L & Male & III & $2 y$ & -- \\
\hline 18 & Bilateral & R & Fem & I & $3 y$ & -- \\
\hline 19 & Bilateral & L & Fem & IV & $3 y$ & -- \\
\hline
\end{tabular}

R: right; L: left; Fem: female; y: years; m: months; --: no recurrence. 


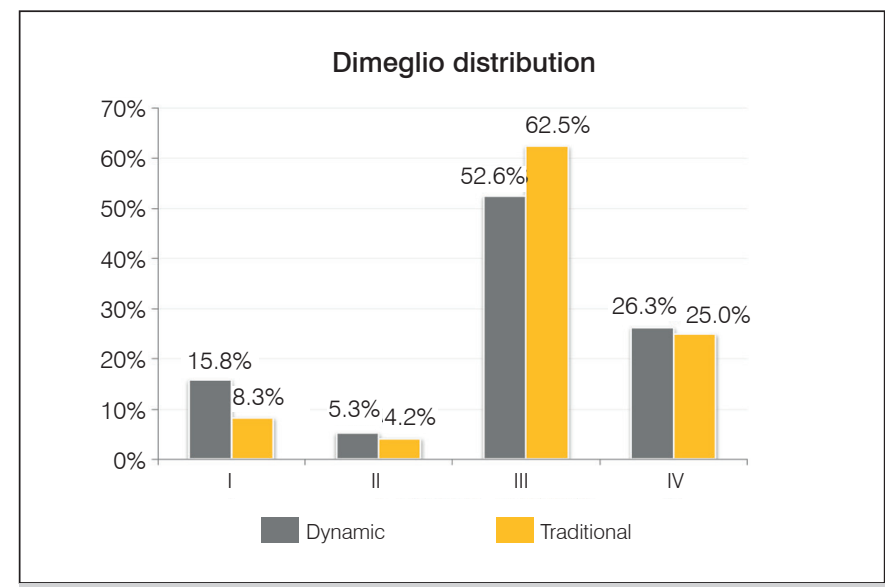

Figure 3. Distribution of groups by Dimeglio classification.

and consists of two shoes connected horizontally by a bar. The unaffected foot is maintained with external rotation of $30^{\circ}-40^{\circ}$ and affected foot is maintained at $60^{\circ}-70^{\circ}$, with dorsiflexion of 10 to $15^{\circ}$. The distance between the feet should be the same as the distance between the child's shoulders. ${ }^{1,3,7,13,19}$ This group was composed of 16 patients totaling 24 idiopathic congenital clubfeet; 12 patients were male and four were female. As for laterality and affected side, eight feet were unilateral and eight were bilateral, 11 left feet and 13 right feet. According to the Dimeglio assessment, two feet were classified as grade I, one as grade II, 15 as grade III, and 6 as grade IV. (Tables 1 and 3 )

Group 2 was treated with a dynamic device which independently provides flexion-extension to each leg with movement in a single plane, preserving muscle strength and restricting the child less. The bar has a central release mechanism, which ensures easy handling in daily activities. The affected foot uses the same degrees of external rotation and dorsiflexion as the traditional device. (Figure 2) This group consisted of 12 patients with a total of 19 CCFs; nine were male and three were female. As for laterality and affected side, five feet were unilateral and seven were bilateral, 11 left feet and eight right feet. According to the Dimeglio assessment, three feet were classified as grade I, one as grade II, 10 as grade III, and 5 as grade IV. (Tables 2 and 3 )

The study included patients who used abduction orthotics for a minimum period of two years.

The average time the orthotics were used was 3.52 years for Group 1 and 2.62 years for Group 2. The minimum time the device was used was two years for both groups, and the maximum time was 5.0 years for Group 1 and 4.0 years for Group 2. (Figure 4)

Patients who did not adhere to device use or who dropped out of treatment (did not return for outpatient follow-up) were excluded. The adults responsible for the patients were advised about the need to return periodically for appointments and particularly about the importance of using the abduction device for the treatment to be successful. In addition, weekly lectures explaining the method were given to the family before appointments. ${ }^{1}$

The Ponseti method consists of weekly manipulations and replacements of plaster casts. The goal is to achieve the simultaneous correction of the cavus, varus, and adduct deformities of the foot. When gains are not obtained from correction and the deformity remains strong in equinus, percutaneous tenotomy of the calcaneal tendon is performed and is followed by plaster casting at the surgical center. The immobilizing cast should remain in place for three weeks. After the casts are removed, the abduction device is kept on the corrected foot for a period of 23 hours per day for the first four months, followed by 12 hours at night for three or four years. ${ }^{11,12}$
Table 3. Comparison of orthotic groups for Dimeglio distribution.

\begin{tabular}{c|c|c|c|c|c}
\hline \multirow{2}{*}{ Dimeglio } & \multicolumn{2}{|c|}{ Dynamic } & \multicolumn{2}{|c|}{ Traditional } & \multirow{2}{*}{ P-value } \\
\cline { 2 - 5 } & $\mathbf{N}$ & $\%$ & $\mathbf{N}$ & $\%$ & \\
\hline I & 3 & $15.8 \%$ & 2 & $8.3 \%$ & 0.449 \\
\hline II & 1 & $5.3 \%$ & 1 & $4.2 \%$ & 0.865 \\
\hline III & 10 & $52.6 \%$ & 15 & $62.5 \%$ & 0.515 \\
\hline IV & 5 & $26.3 \%$ & 6 & $25.0 \%$ & 0.922 \\
\hline
\end{tabular}

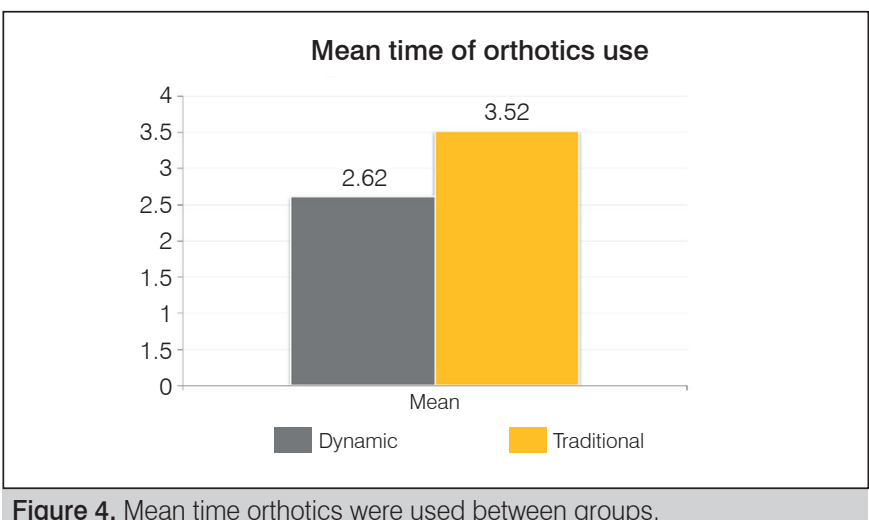

If the deformity recurs while the abduction device is being used, treatment is reinitiated and a new series of plaster casts is placed until the deformity is completely corrected. If necessary, tenotomy of the calcaneal tendon can be performed again. The corrected foot then returns to the abduction brace. We consider recurrence to be all cases in which the initial CCF deformities returned after the treatment described above.

This study was approved by the institutional review board.

The statistical analysis compared the categorical variables between the groups using the ANOVA test. A significance level of $5 \%$ was adopted ( $p$-value $\leq 0.05$ ).

Through this analysis, we evaluated the effectiveness of the orthotics and whether one type was more effective.

\section{RESULTS}

The results were considered satisfactory for feet in which all components of the deformity were corrected, and unsatisfactory when these components recurred.

In Group 1 recurrence was observed in two feet (8.33\%), and in Group 2 in one foot (5.26\%); in both groups the recurrences were equinus, cavus, and adduct in a much less acute form than the initial deformity. These feet again underwent serial plaster casting of the feet and legs until the deformities were completely corrected, and then returned to the use of the abduction brace device. (Figure 5) There was no statistically significant difference in efficacy between the groups. The groups were homogeneous for the variables Dimeglio classification, sex, side, laterality, and recurrence $(p=0.695)$, with no statistical difference between the groups. (Tables $1-4)$ No complications related to the method (casting and tenotomy) or prostheses used were seen in either group.

\section{DISCUSSION}

The Ponseti method for treating idiopathic CCF has proven consistently successful in correcting deformities. Studies of this method emphasize that the period during which the abduction appliance is used is a very important step for maintaining the correction of the deformities. ${ }^{1,10,13,19}$ Correction of the sagittal plane in CCF can be maintained by connecting the feet horizontally with a metal bar and positioning them at the desired angles in fixed bases. ${ }^{11}$ 


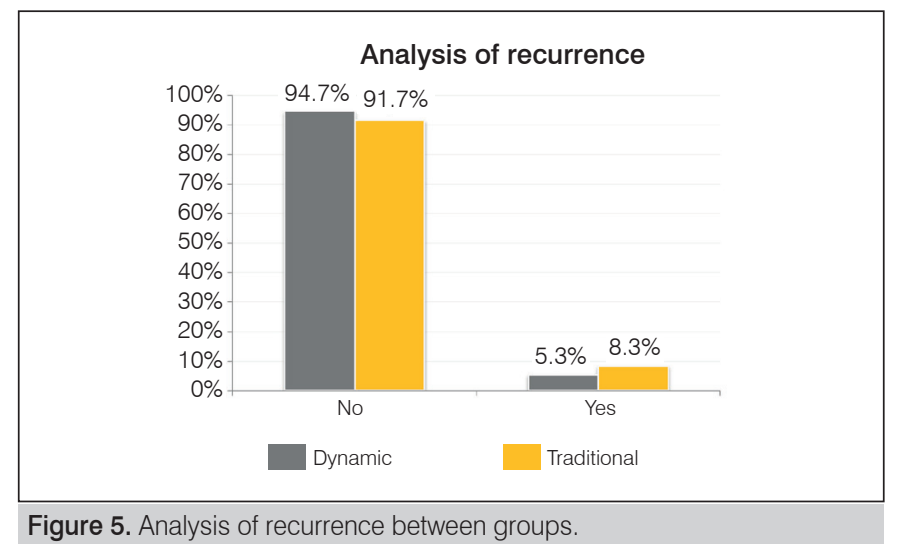

Table 4. Comparison of orthotic groups for distribution of recurrence.

\begin{tabular}{c|c|c|c|c|c}
\hline \multirow{2}{*}{ Recurrence } & \multicolumn{2}{|c|}{ Dynamic } & \multicolumn{2}{|c|}{ Traditional } & \multirow{2}{*}{ P-value } \\
\cline { 2 - 5 } & N & $\%$ & N & $\%$ & \\
\hline No & 18 & $94.7 \%$ & 22 & $91.7 \%$ & \multirow{2}{*}{0.695} \\
\hline Yes & 1 & $5.3 \%$ & 2 & $8.3 \%$ & \\
\hline
\end{tabular}

A study by Ponseti13 on recurrence of CCF deformities showed in patients who do not adhere to the use of orthotics, the recurrence rate is $78 \%$, compared with only $7 \%$ in those who correctly use the devices. Based on these principles, in this study we only included patients whose family members were committed to the treatment and complied with outpatient follow-up, and consequently we were able to compare and evaluate the effectiveness of these two types of prostheses. The incidence of deformity was in line with the literature with respect to sex; ${ }^{3}$ males were affected more often than females, at a ratio of three to one in Group 1 and five to one in Group 2. (Figure 3)
In their 1963 work, Ponseti and Smoley ${ }^{6}$ achieved success in $80 \%$ of their cases. After refining their method, in 2002 these same authors published a study with only $7 \%$ recurrence..$^{13}$ In this present study, the recurrence rate in Group 1 was $8.33 \%$ of the feet, very close to findings of other studies. ${ }^{7,10,13}$ Verma et al. ${ }^{14}$ reported that in treating older children with idiopathic CCF aged from one to three years, recurrence was higher, around 11\%. In Group 2, which used the dynamic orthotic device, the recurrence rate was $5.26 \%$, less than in Group 1 but more than the rate found by Dobbs et al. ${ }^{9}$ using the same orthotics, $3.6 \%$.

We agree with Zhao et al..$^{10}$ on the importance of developing new orthotics in order to provide comfort and tolerance for both children and parents, thus increasing adherence to the proposed protocol of use as well as the efficacy of treatment, thus reducing the rate of recurrence. The family members of these children often complain that the traditional abduction device is more uncomfortable, keeping the feet in a fixed position with little mobility and in many cases encouraging non-adherence to treatment. ${ }^{3,5,12,17,18}$ Dobbs et al. ${ }^{9}$ used more dynamic orthotics and noted greater satisfaction in both parents and children.

This study found that both the classic and the dynamic orthotic devices were effective in maintaining the correction of idiopathic CCF deformities, and consequently allow more participation by the parents in selecting the type of device (dynamic or static); the family was more involved and cooperated significantly to achieve better results in treating this important disease.

\section{CONCLUSIONS}

Both the classic and dynamic abduction orthotic devices proved effective for maintaining correction of congenital clubfoot deformities. There was no statistical significance in relation to type of orthotics used and recurrence.

AUTHORS' CONTRIBUTIONS: Each author made significant individual contributions to this manuscript. LCATF (0000-0002-0778-2506)* and LCRL $(0000-0003-1158-2643)^{*}$ were the main contributors in drafting the manuscript. BLG (0000-0001-9133-0176)* and TPSS $(0000-0001-5606-4896)^{\star}$ collected the clinical data through retrospective analysis of the patient records. TPSS (0000-0001-5606-4896)* evaluated the statistical analysis and compared the categorical variables between the groups using ANOVA. TPSS (0000-0001-5606-4896** and LCATF (0000-0002-0778-2506) reviewed the literature. LCRL (0000-0003-1158-2643)* revised and approved the final version of the manuscript. *ORCID (Open Researcher and Contributor ID).

\section{REFERENCES}

1. Lara LCR, Montesi Neto DJC, Prado FR, Barreto AP. Tratamento do pé torto congênito idiopático pelo método de Ponseti: 10 anos de experiência. Rev Bras Ortop. 2013;48(4):362-7

2. Lara LCR, Bergamasco JMP, Marques AFS, Luciano RP. Tratamento cirúrgico do pé torto congênito idiopático: resultados com 15 anos de seguimento. Rev ABTPé. 2012;6(2):81-9.

3. Desai L, Oprescu F, DiMeo A, Morcuende JA. Bracing in the treatment of children with clubfoot: past, present, and future. lowa Orthop J. 2010;30:15-23.

4. Boehm S, Limpaphayom N, Alaee F, Sinclair MF, Dobbs MB. Early results of the Ponseti method for the treatment of clubfoot in distal arthrogryposis. J Bone Joint Surg Am. 2008;90(7):1501-7.

5. Dobbs MB. Clubfoot: etiology and treatment: editorial comment. Clin Orthop Relat Res. 2009;467(5):1119-20.

6. Ponseti IV, Smoley EN. Congenital clubfoot: the results of treatment. J Bone Joint Surg Am. 1963;45:261-75

7. Ponseti IV. Treatment of congenital club foot. J Bone Joint Surg Am. 1992:74(3):448-54

8. Diméglio A, Bensahel H, Souchet P, Mazeau P, Bonnet F. Classification of clubfoot. J Pediatr Orthop B. 1995;4(2):129-36.

9. Dobbs MB, Rudzki JR, Purcell DB, Walton T, Porter KR, Gurnett CA. Factors predictive of outcome after use of the Ponseti method for the treatment of idiopathic clubfeet. J Bone Joint Surg Am. 2004;86-A(1):22-7.

10. Zhao D, Liu J, Zhao L, Wu Z. Relapse of clubfoot after treatment with the Ponseti method and the function of the foot abduction orthosis. Clin Orthop Surg. 2014;6(3):245-52.
11. Staheli L. Clubfoot: Ponseti management [Internet]. 3rd ed. Seattle, WA: Global HELP; 2009 [cited 2013 Nov 20]. Available from: http://www.global-help.org/ publications/books/ book_cfponseti.html.

12. Chen RC, Gordon JE, Luhmann SJ, Schoenecker PL, Dobbs MB. A new dynamic foot abduction orthosis for clubfoot treatment. J Pediatr Orthop. 2007;27(5):522-8.

13. Ponseti IV. Relapsing clubfoot: causes, prevention, and treatment. lowa Orthop J. 2002;22:55-6

14. Verma A, Mehtani A, Sural S, Maini L, Gautam VK, Basran SS, et al. Management of idiopathic clubfoot in toddlers by Ponseti's method. J Pediatr Orthop B. 2012;21(1):79-84

15. George HL, Unnikrishnan PN, Garg NK, Sampath J, Bruce CE. Unilateral foot abduction orthosis: is it a substitute for Denis Browne boots following Ponset technique? J Pediatr Orthop B. 2011;20(1):22-5.

16. Avilucea FR, Szalay EA, Bosch PP, Sweet KR, Schwend RM. Effect of cultural factors on outcome of Ponseti treatment of clubfeet in rural America. J Bone Joint Surg Am. 2009;91(3):530-40.

17. Kessler JI. A new flexible brace used in the Ponseti treatment of talipes equinovarus. J Pediatr Orthop B. 2008;17(5):247-50.

18. Hemo Y, Segev E, Yavor A, Ovadia D, Wientroub S, Hayek S. The influence of brace type on the success rate of the Ponseti treatment protocol for idiopathic clubfoot. J Child Orthop. 2011;5(2):115-9.

19. Janicki JA, Wright JG, Weir S, Narayanan UG. A comparison of ankle foot orthoses with foot abduction orthoses to prevent recurrence following correction of idiopathic clubfoot by the Ponseti method. J Bone Joint Surg Br. 2011;93(5):700-4 